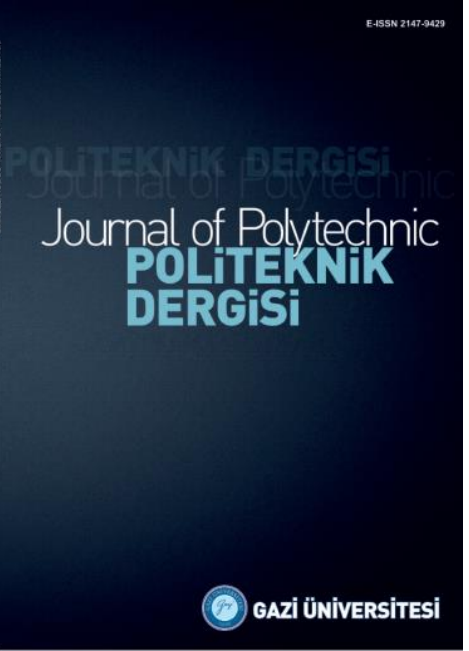

POLITEKNIK DERGISI

\author{
JOURNAL Of POLYTECHNIC
}

ISSN: 1302-0900 (PRINT), ISSN: 2147-9429 (ONLINE)

URL: http://dergipark.org.tr/politeknik

\title{
Inertia and droop controller for a modern variable speed wind turbine to provide frequency control in a microgrid
}

Modern değișken hızlı rüzgar türbini için mikro şebekede frekans kontrolü sağlayabilecek atalet ve frekans eğim tepkisi kontrolörü

Yazar(lar) (Author(s)): Ali HASSAN ${ }^{1}$, Müfit $A L T I N^{2}$, Ferhat BINGÖL ${ }^{3}$

ORCID': 0000-0003-2405-7741

ORCID²: 0000-0002-3650-3131

ORCID3: 0000-0002-8071-3814

Bu makaleye șu șekilde atıfta bulunabilirsiniz(To cite to this article): Hassan A., Altin M. and Bingöl F., "Inertia and droop controller for a modern variable speed wind turbine to provide frequency control in a microgrid", Politeknik Dergisi, 23(3): 771-777, (2020). 


\title{
Inertia and Droop Controller for a Modern Variable Speed Wind Turbine to Provide Frequency Control in a Microgrid
}

\section{Highlights}

* Modelling of Type D wind turbine in MATLAB/Simulink.

* Inertia and Droop controllers are designed and their performance in providing frequency support is compared.

\section{Graphical Abstract}

Inertia and droop controllers are designed and their performance in provideing frequency control in an isolated power system containg one steam turbine genrator and wind farm is compared.

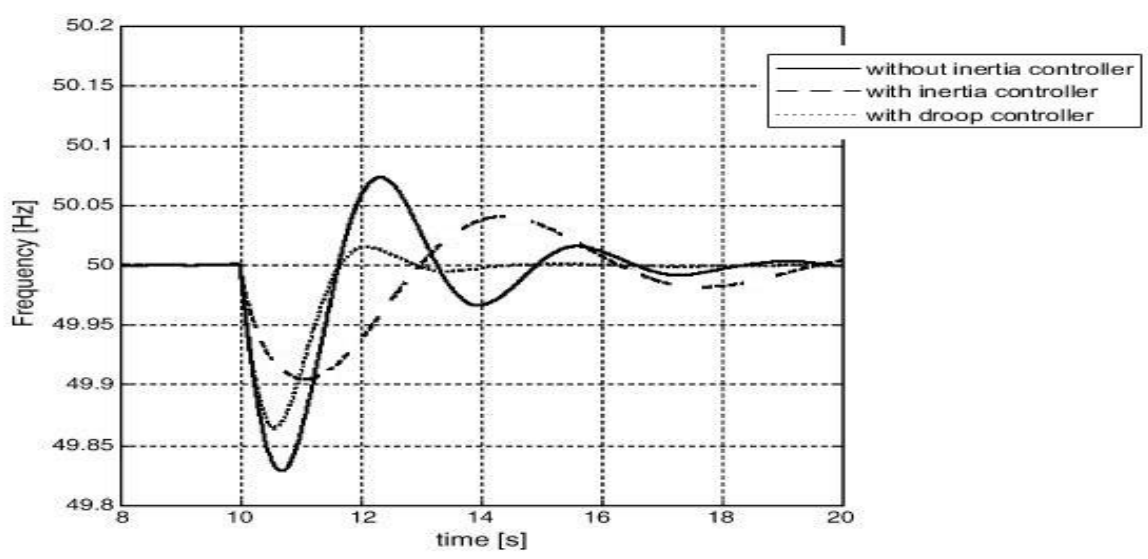

Figure. Frequency deviation after disturbance. a) Without inertial controller - solid line

b)with inertial controller - dashed line c) with droop controller - dotted line

\begin{abstract}
Aim
To design droop and Inertia controller for a Variable Speed Wind Turbine to control frequency fluctions in an isolated power system.
\end{abstract}

\section{Design \& Methodology}

Modelling of a Type D wind turbine retrofitted with droop and inertia controllers in MATLAB/Simulink.

\section{Originality}

The comparison of the two types of controllers (Inertia and Droop) has been attempted for the first time in this article.

\section{Findings}

Modern Variable Wind Turbines provide a better primary frequency control support when retrofitted with inertia or droop controllers.

\section{Conclusion}

The results show that inertial and the droop controllers, support the dropping frequency which is vital in isolated power systems with high wind power penetration with less spinning reserve.

\section{Declaration of Ethical Standards}

The author(s) of this article declare that the materials and methods used in this study do not require ethical committee permission and/or legal-special permission. 


\title{
Modern Değişken Hızlı Rüzgar Türbini İçin Mikro Şebekede Frekans Kontrolü Sağlayabilecek Atalet ve Frekans Eğim Tepkisi Kontrolörü
}

\author{
Araştırma Makalesi/Research Article \\ Ali HASSAN ${ }^{1}$, Müfit ALTIN²*, Ferhat BİNGÖL ${ }^{2}$ \\ ${ }^{1}$ Energy Engineering MSc. Programme, Izmir Institute of Technology (IYTE), Izmir, Turkey \\ ${ }^{2}$ Department of Energy Systems Engineering, Izmir Institute of Technology (IYTE), Izmir, Turkey \\ (Geliş/Received : 22.06.2019; Kabul/Accepted : 05.09.2019)
}

ÖZ

\begin{abstract}
Modern Değişken Hızlı Rüzgar Türbinlerinin (VSWT) mikro şebekelerde artan varlığı, güç sisteminin ataletinin azalması nedeniyle frekans stabilizasyonu sorunu yaratmaktadır. Geleneksel senkron makinelerin Atalet Tepkisi taklit etmek için, rüzgar türbinlerine bir atalet emülasyon denetleyicisi sağlanabilir. Bu yazıda sunulan modelleme, modern D Tipi rüzgar türbininin atalet tepkisi ve birincil frekans kontrolü (PFC) yetenekleri ile donatılmasını amaçlamaktadır. İki kontrol cihazı - atalet ve frekans eğim tepkisi, uygulanır ve frekans kontrol yetenekleri, geleneksel bir buhar türbini jeneratörü ve rüzgar tarlasında oluşan izole edilmiş güç sistemi ile karşılaştırılır. Elde edilen sonuçlar, önerilen kontrol cihazlarının mikro şebekedeki daha iyi frekans kontrol performansına yardımcı olduğunu göstermektedir.
\end{abstract}

Anahtar Kelimeler: Atalet emülasyon, rüzgar türbini, frekans kontrolü.

\section{Inertia and Droop Controller for a Modern Variable Speed Wind Turbine to Provide Frequency Control in a Microgrid}

\begin{abstract}
The increasing penetration of modern Variable Speed Wind Turbines (VSWTs) in microgrids creates the problem of frequency stabilization due to reduced inertia of the power system. To emulate the Inertia Response of the conventional synchronous machines, wind turbines can be provided with an inertia emulation controller. The modeling presented in this paper aims at equipping the modern Type D wind turbine with inertia response and primary frequency control (PFC) capabilities. Two controllers - inertial and droop, are implemented and their frequency control capabilities are compared in an isolated power system which consists of a conventional steam turbine generator and a wind farm. The results suggest that proposed controllers help in better frequency control performance in the microgrid.
\end{abstract}

Keywords: Inertia emulation, wind turbine, frequency control.

\section{INTRODUCTION}

The exhaustion of the fossil fuels and environmental concerns have sped up the installation of renewable energy resources in the last decade. Wind and Solar are among the most utilized renewable sources around the globe [1]. Although the wind energy is nearly emission free, it exhibits an intermittent behavior. This intermittency poses major challenges for the integration of high penetration of wind in the power system. The wind power is predicted to further increase its share in the electric power generation.

The trend of small or isolated power systems (microgrids) with high penetration of wind is also increasing. Microgrids are a small power energy networks in which electrical loads are fed by a

*Sorumlu Yazar (Corresponding Author)

e-posta : mufitaltin@iyte.edu.tr combination of Distributed Energy Resources (DERs) and conventional generation. The capability of conventional generation to provide Inertia Response (IR) or Primary Frequency Control (PFC) is limited in microgrids. Modern Variable Speed Wind Turbine (VSWT) use back-to-back electronic converter for the connection to the grid [2] which isolates the grid frequency from the Wind Turbine Generator (WTG) and the overall inertia of the system goes down. Consequently, high Rate of Change of Frequency ( RoCoF) is noticed in microgrids in the case of a contingency or sudden load disturbance. The high wind penetration creates frequency stabilization issues and there is an increasing need for the wind turbines to play an active role in the frequency control. Providing additional reserve margin by the conventional generation to integrate wind power increases economic costs [2]. One way to provide the frequency control through wind turbine is Deloading [3] in which turbines are operated 
below their capacity to provide a ramp up in the power in the case of frequency drop. It can be done through pitch control [4] and speed control [5]. The drawback, however, of such an operation is the economic loss incurred due to turbines not operating at their maximum potential. Other methods include using the wind turbines in combination with Battery Energy Storage Systems (BESS) and fuel cells. In related studies [6], the researchers propose a control strategy that uses conventional plant's output electrical power as a reference power for VSWT so that VSWT injects an additional power $(\triangle P)$ after the imbalance.

The contribution of this paper is the design of two types of controllers - inertial and droop, for a modern variable speed wind turbine to enable it to provide the inertial response to alleviate the frequency drop in the case of frequency drop due to a fault.

In next section, a theoretical isolated power system used in our study, is introduced, followed by the modelling of various components of a "Type D" wind turbine and steam turbine generator in section 3 and 4 respectively. Section 5 and 6 are related to the inertia and droop controller. Section 6 shows the results followed by conclusions.

\section{MICROGRID MODELLING}

A microgrid is an electricity distribution system containing electrical loads and DERs that can be operated in controlled coordinated way while connected to the main grid or in isolation [7]. The test system in Figure 1 that is modelled in this study consists of a conventional steam turbine generator operating along a wind farm consisting of four modern VSWTs. The system is isolated from the main grid. Various parameters of this microgrid are given in Table 1. For this system the wind penetration level - defined as a ratio of total annual wind energy to gross annual demand - is 13 percent which is considered as high and can be used to simulate the contribution of wind turbines in frequency control of a microgrid [8]. A block diagram of microgrid is represented in Figure 2

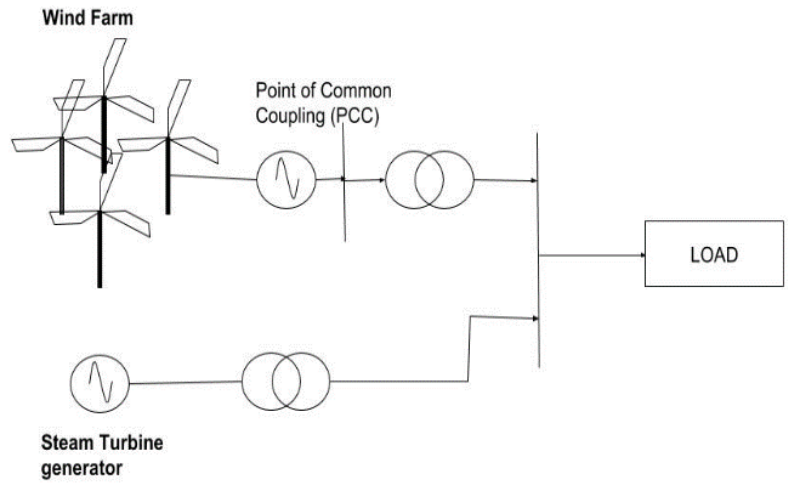

Figure 1. Isolated power system with a steam turbine generator and a wind farm (one-line diagram)
Table 1. Parameters of isolated power system used in our study

\begin{tabular}{ll}
\hline Wind generation & $4 \times 2=8 \mathrm{MW}$ \\
\hline Steam turbine Generation & $50 \mathrm{MW}$ \\
\hline Load & $50 \mathrm{MW}$ \\
\hline
\end{tabular}

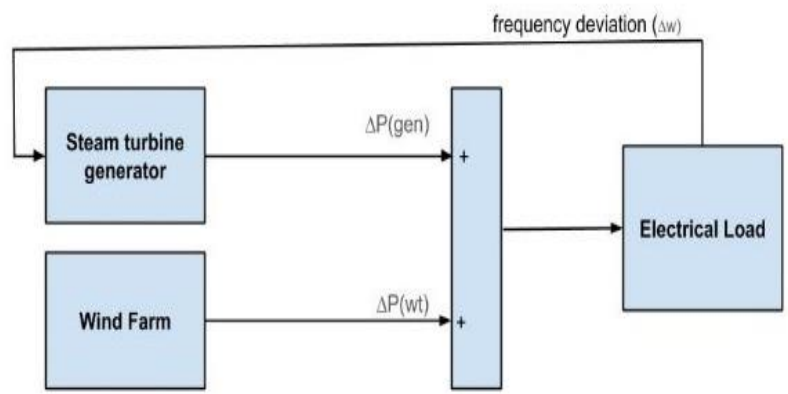

Figure 2. Isolated power system with a steam turbine generator and a wind farm (block diagram)

\section{MODELLING OF A TYPE D WIND TURBINE}

A Type D wind turbine is chosen in the study because it is widely utilized modern VSWT. Most of the current and future wind farms use this latest wind turbine type that makes its contribution to frequency control essential. The wind turbine modelling is the initial step towards integrating new control features on wind power plant (WPP) level. The components of the wind turbine include a rotor connected to the generator through a gear box. The interface between WTG and the grid in type D wind turbine is through a full-scale frequency convertor consisting of a rotor side convertor and a grid side convertor as shown in Figure 3.

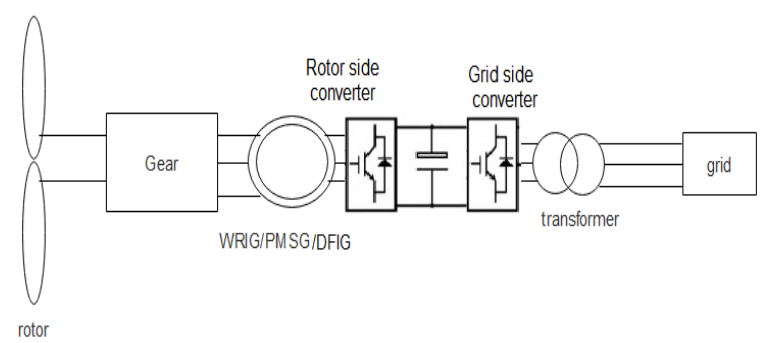

Figure 3. Type D VSWT model proposed by International Electrotechnical Commission (IEC)

The parameters used for this standard reference wind turbine model correspond to a $2 \mathrm{MW}$ type $\mathrm{D}$ wind turbine proposed by International Electrotechnical Commission (IEC) in IEC61400-27-1[9] having the specifications shown in Table 2.

The power curve depicted in Figure 4 consists of power optimization and power limitation zone which means that the turbine's aim is to optimize power production when the wind speed is between the cut-in and rated value. Whereas, for the wind speed values between the rated and cut-off, the pitch control limits the power production due to safety reasons. 
Table 2. Parameters of a type D VSWT

\begin{tabular}{ll}
\hline Wind turbine power rating $(\mathrm{MW})$ & 2 \\
\hline Cut-in wind speed $(\mathrm{m} / \mathrm{s})$ & 3 \\
\hline Rated wind speed $(\mathrm{m} / \mathrm{s})$ & 11.6 \\
\hline Cut-out wind speed $(\mathrm{m} / \mathrm{s})$ & 25 \\
\hline Height $(\mathrm{m})$ & 100 \\
\hline Turbine diameter $(\mathrm{m})$ & 80
\end{tabular}

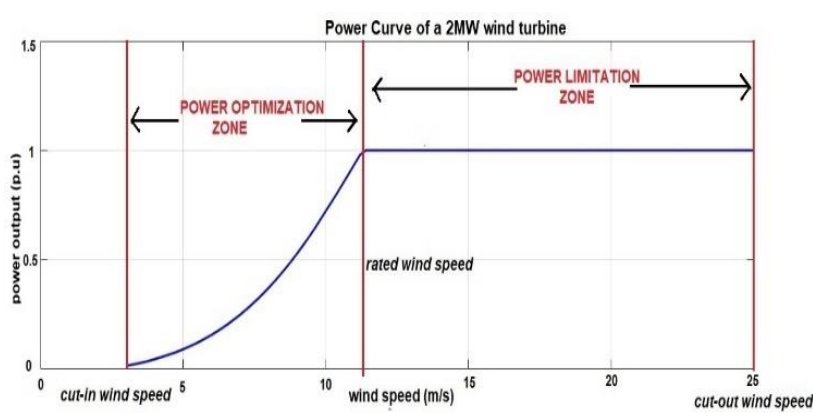

Figure 4. power curve of a $2 \mathrm{MW}$ wind turbine

Various blocks of the model simulated in Simulink are shown in Figure 5.These blocks are I) Aerodynamic model II) Pitch controller III) Mechanical model and IV) Maximum Power Point Tracking (MPPT) block[9].

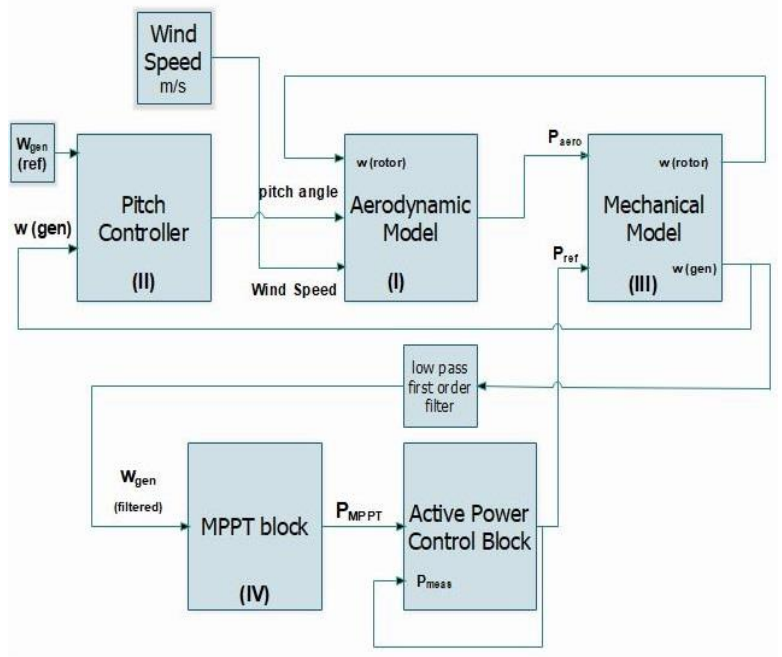

Figure 5. Block diagram of a type D wind turbine

The aerodynamic model is the interface between the incoming wind $(\mathrm{m} / \mathrm{s})$ and the wind turbine blades. The block gives aerodynamic power $\left(P_{\text {aero }}\right)$ as an output which is fed to the mechanical model. The mechanical model determines the speed of generator $\left(w_{\text {gen }}\right)$ used as an input to MPPT block which gives the electrical power output corresponding to the generator speed based on the power curve. The pitch control keeps the rotation of wind turbine blades in check by comparing the error between actual generator speed $\left(w_{\text {gen }}\right)$ and nominal generator speed $\left(w_{\text {gen }(r e f)}\right)[10]$.

\subsection{Aerodynamic Model}

The equation for the aerodynamic power of the WT is given by

$$
P=\frac{1}{2} \rho \pi R^{2} U^{3} C_{p}(\lambda, \beta)
$$

where,

$\rho$ is the density of the air, $R$ is the radius of the turbine rotor in meters, $U$ is the wind speed in $\mathrm{m} / \mathrm{s}, C_{p}$ is the power coefficient, $\lambda$ is the Tip Speed Ratio (TSR) and $\beta$ is the pitch angle.

Figure 6 shows the Simulink diagram of the aerodynamic model. The $C p-\lambda-\beta$ table is used as a 2-D lookup table in the model. TSR $\lambda$ is given by

$$
\lambda=\frac{w_{\text {rotor }} R}{U}
$$

where, $w_{\text {rotor }}$ is the rotating speed of the turbine blades.

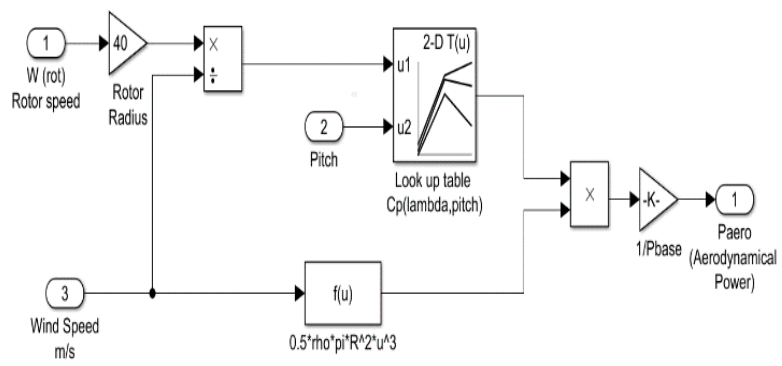

Figure 6. Simulink diagram of aerodynamic model

\subsection{Pitch Controller}

In VSWT, pitch controller changes the pitch angle of the turbine blades against the wind to change the power output. The PI control system generates a reference blade angle and the pitch servo motor serves as an actuator turning the blades to a certain angle. In Figure 7 the error between the generator's actual speed and its nominal speed is fed as an input to the PI controller which generates the reference value which is further compared to the actual pitch angle. The actuator sets the new pitch angle according to the WTG speed. The pitch servo is subjected to angle limitations, $\beta_{\min }$ and $\beta_{\max }$ providing a certain limit of angles within which the blades can turn. Likewise, there is also a pitch speed limitation, $\frac{d \beta}{d t}$ which is the limit to the rate of change of angle of the turbine's blade.

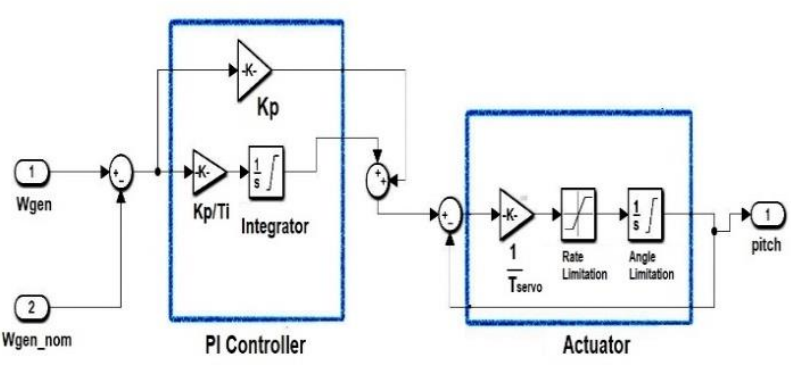

Figure 7. Simulink model of Pitch controller 
The pitch controller remains passive in the power optimization zone during which the optimal value of the pitch is zero. It is activated only when the wind turbine is operating in its power limitation zone i.e. the case of high wind speeds when there is a need to cap the output by limiting rotor's rotation speed.

\subsection{Mechanical Model}

The drive train is taken into consideration in mechanical model which is connected on one side (Low speed, $L S$ side) with the turbine's rotor blades and on the other side (High Speed. HS side) with the generator. The LS turbine rotations are converted into HS generator rotations through a gearbox. The high-speed shaft is assumed to be stiff whereas the low speed shaft is assumed to be flexible with a stiffness ' $k$ ' and damping coefficient ' $c$ ' as shown in Figure 8.

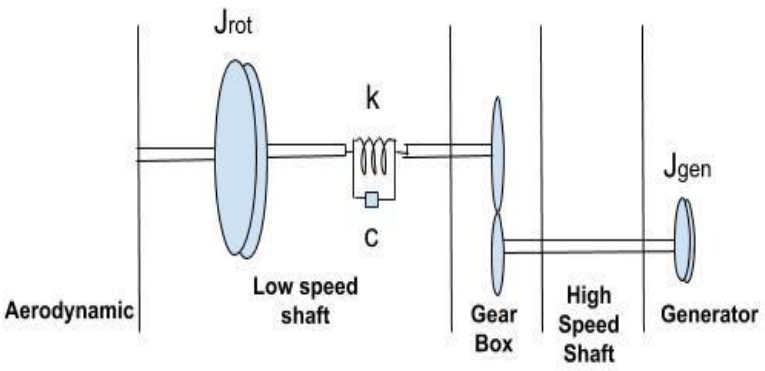

Figure 8. Mechanical model

According to basic formula of rotational motion the torque $T$ is given as a product of inertia $J$ and rotational acceleration $\boldsymbol{\alpha}$ which is a double derivative of angle of rotation, i.e. $\ddot{\theta}$. Therefore, the dynamical behavior of mechanical model is governed by the following mathematical equations,

$$
\begin{gathered}
T_{\text {rot }}-T_{\text {shaft }}=J_{\text {rot }} \ddot{\theta}_{\text {rot }} \\
T_{\text {shaft }}-T_{\text {gen }}=J_{\text {gen }} \ddot{\theta}_{\text {gen }} \\
T_{\text {shaft }}=k \Delta \theta+c \Delta \omega \\
T_{\text {shaft }}=k\left(\theta_{\text {rot }}-\frac{\theta_{\text {rot }}}{n_{\text {gear }}}\right)+c\left(\dot{\theta}_{\text {rot }}-\frac{\dot{\theta}_{\text {rot }}}{n_{\text {gear }}}\right)
\end{gathered}
$$

where

$T_{\text {rot }}$ is aerodynamic torque

$T_{\text {shaft }}$ is mechanical torque of flexible shaft

$T_{\text {gen }}$ is generator torque

$J_{\text {gen }}$ is generator inertia

$J_{\text {rot }}$ is the rotor inertia

$\theta_{\text {gen }}$ is generator angle

$\Delta \theta$ is the angular difference

$\Delta \omega$ is the speed difference between two ends of a shaft $k$ is the stiffness

$c$ is the damping coefficient

$\theta_{\text {rot }}$ is a rotor angle

$n_{\text {gear }}$ is the gear ratio

$H$ is the inertia time constant and is given by,

$$
H=\frac{J w_{\text {base }}{ }^{2}}{2 P_{\text {base }}}
$$

The equations (3)-(6) can be transformed by taking Laplace transform [9]

$$
\begin{gathered}
w_{\text {rot } p . u}=\frac{1}{2 s H_{\text {rot } p . u}}\left(T_{\text {rot p.u }}-T_{\text {shaft } p . u}\right) \\
w_{\text {gen } p . u}=\frac{1}{2 s H_{\text {gen } p . u}}\left(T_{\text {shaft } p . u}-T_{\text {gen } p . u}\right) \\
T_{\text {shaft } p . u}=k \Delta \theta_{p u}+c \Delta w_{p u}
\end{gathered}
$$

where,

$P_{(a e r o)}$ is aerodynamic power

$H_{r o t}$ is the wind turbine's rotor inertia

$w_{\text {rot }}$ is the rotor speed

$P_{(\text {meas }}$ is the measured power

$H_{g e n}$ is the constant inertia of the generator

$w_{\text {gen }}$ is the generator speed

$k$ is the shaft stiffness

$c$ is the damping constant

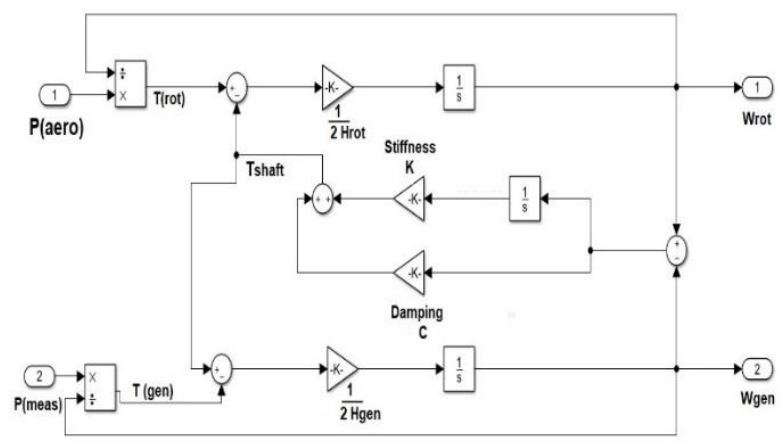

Figure 9. Simulink diagram of mechanical model

Equations (7)-(9) are used to implement the two-mass model behavior shown in

Figure 9. The values are calculated in per unit.

3.4. Maximum Power Point Tracking (MPPT) block

1-D lookup table showing relation between power output of turbine $\left(P_{\text {ref }}\right)$ and generator speed $\left(w_{\text {gen }}\right)$ is used to model the MPPT block. The MPPT block takes filtered generator speed as input and gives the optimized power $P($ ref $)$ as an output as shown in Figure 10. 


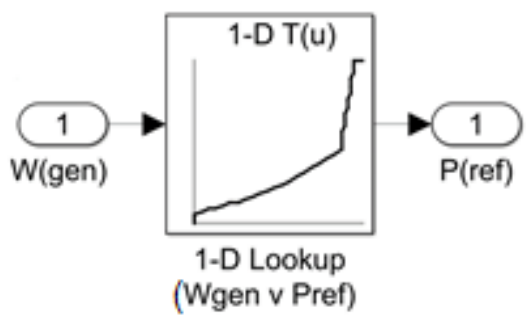

Figure 10. Maximum Power Point Tracking Block

\subsection{Performance of the Wind Turbine Model Against Wind Speed Input.}

The wind turbine model's output $\left(P_{\text {measured }}\right)$ and generator speed $\left(w_{\text {gen }}\right)$ are measured against deterministic and turbulent wind speeds. For a deterministically increasing wind speed from $4 \mathrm{~m} / \mathrm{s}$ to $7 \mathrm{~m} / \mathrm{s}$ (power optimization zone) and from $13 \mathrm{~m} / \mathrm{s}$ to $17 \mathrm{~m} / \mathrm{s}$ (power limitation zone), the power output and generator speed are shown in Figure 11 and Figure 12.

The wind turbine model is then tested for real wind speed data, output of which is shown in Figure 13.
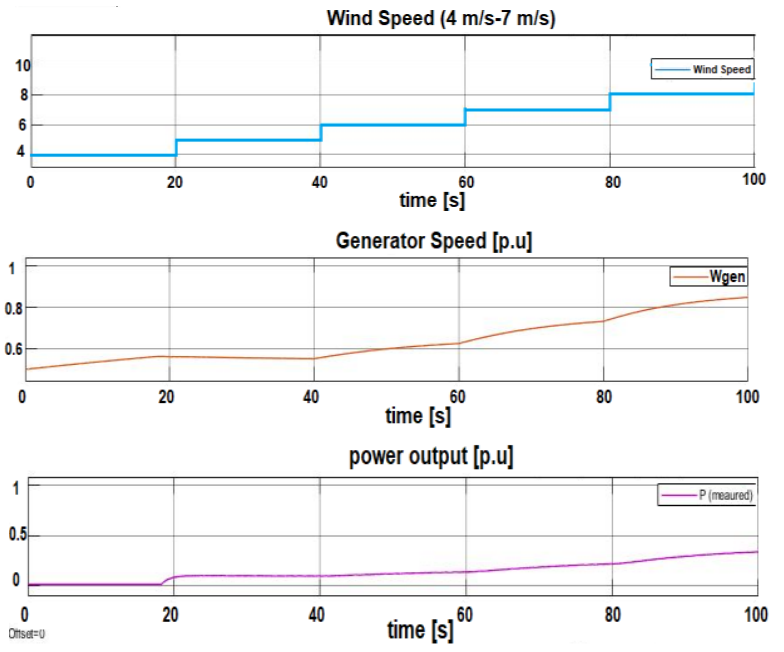

Figure 11. Wind turbine operation against deterministic wind speed $4 \mathrm{~m} / \mathrm{s}$ to $7 \mathrm{~m} / \mathrm{s}$.
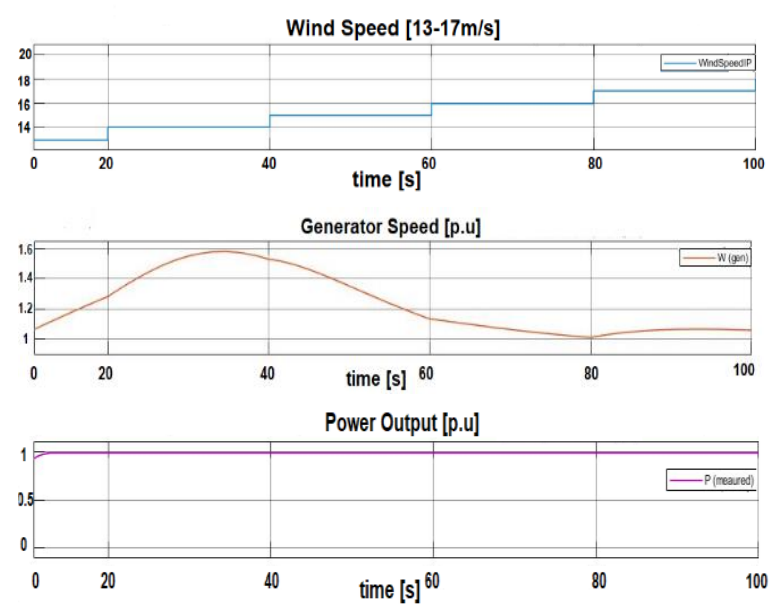

Figure 12. Wind turbine operation against deterministic wind speed $13 \mathrm{~m} / \mathrm{s}$ to $17 \mathrm{~m} / \mathrm{s}$
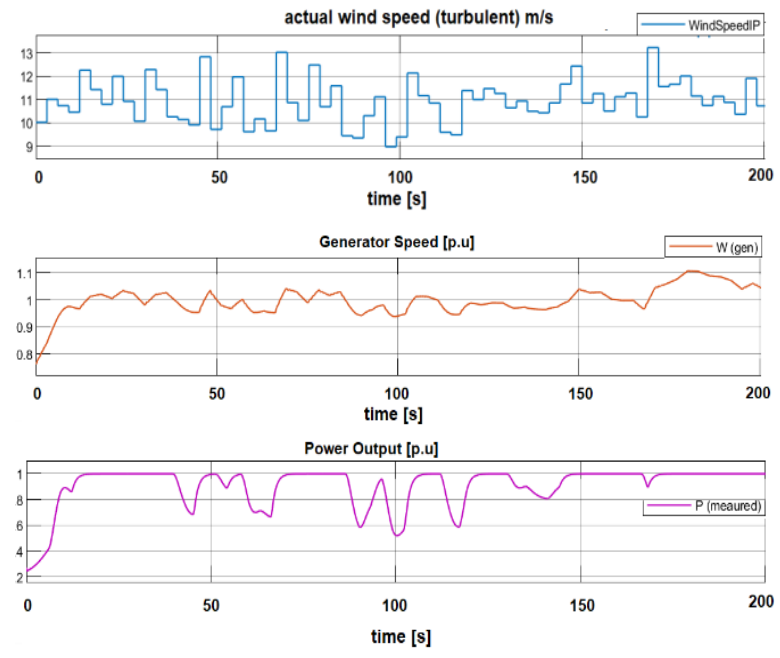

Figure 13. Wind turbine operation against turbulent wind speed data.

\section{STEAM TURBINE GENERATOR MODELLING}

Various components of steam turbine generator are its governor, turbine, prime over and load[11] which are modelled in Figure 14. Various parameters used for the modelling are given in Table 3.

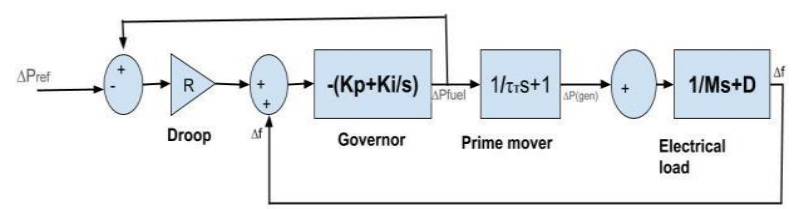

Figure 14. Model of a steam turbine generator

Table 3. Steam Turbine Generator model parameters[12]

\begin{tabular}{ll}
\hline Prime mover time constant $\left(\mathrm{T}_{\mathrm{t}}\right)$ & 2 \\
\hline Governor proportional parameter $\left(\mathrm{K}_{p}\right)$ & 20 \\
\hline Governor integral parameter $\left(\mathrm{K}_{i}\right)$ & 2 \\
\hline Damping (D) & 0.40 \\
\hline Droop (R) & 0.04 \\
\hline
\end{tabular}

\section{INERTIA CONTROLLER}

The equation for inertia controller is given as

$$
\Delta P_{R O C}=-K_{R O C} \frac{d f}{d t}
$$

The inertia controller consists of a derivative block which takes the derivative of the falling frequency and multiplies it with a gain $-K_{R O C}$. The output $\triangle P_{R O C}$ is then added to the normal output $P_{M P P T}$ of wind turbine. The new reference power ' $P$ ref' is then fed to the rotor side converter which sends the signal to the WTG. The generator uses the inherent inertia of the rotor and drive train to generate a surge in power that helps to stabilize the frequency drop. The inertial controller is shown in Figure 15. 


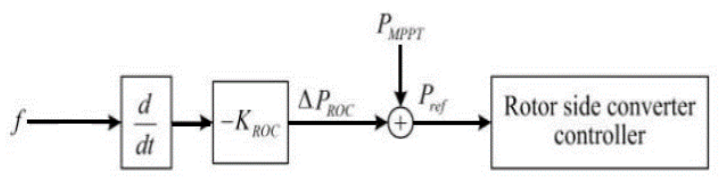

Figure 15. Inertia controller

A wind turbine with the inertia control is shown in a block and schematic diagram in Figure 16 and Figure 17.

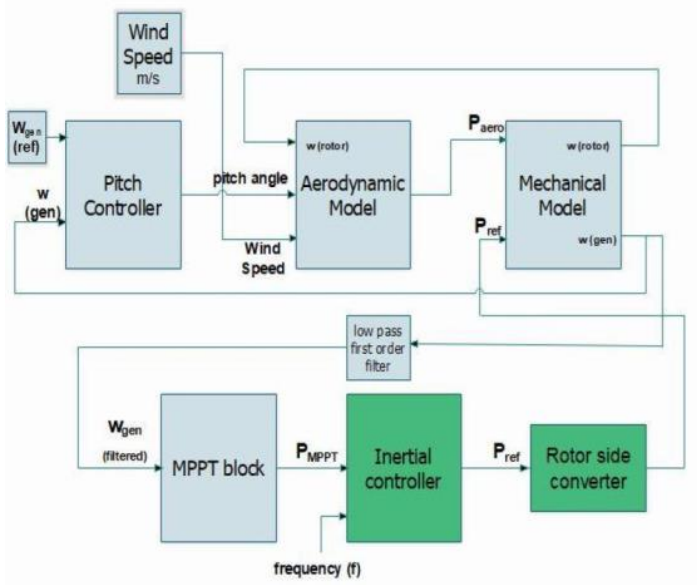

Figure 16. Wind Turbine block diagram with inertial controller

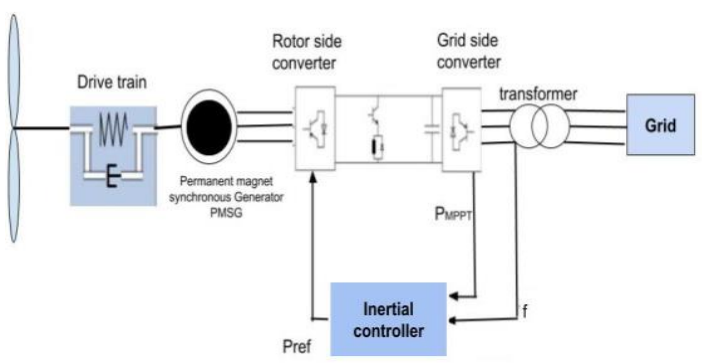

Figure 17. Type D wind turbine with inertial controller

\section{DROOP CONTROLLER}

The droop controller takes the difference between actual frequency $f$ and the nominal frequency $f_{\text {nom }}$ and multiplies it with a gain $-K_{d r o}$. The output $\Delta P_{d r o}$ is added to the normal power output $P_{M P P T}$ of the WT. The equation is given by

$$
\Delta P_{\text {dro }}=-K_{\text {dro }}\left(f-f_{\text {nom }}\right)
$$

Figure 18 shows the droop controller. It also utilizes the inherent inertia of wind turbines rotor to generate the surge of power. The block diagram of a wind turbine with a droop controller is represented in Figure 19.

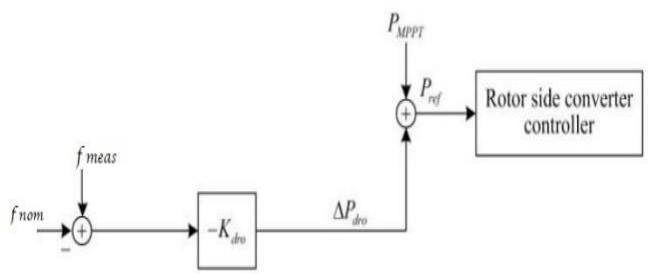

Figure 18. Droop controller

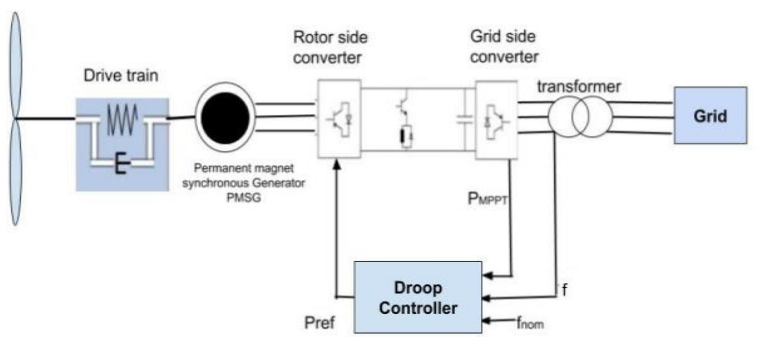

Figure 19. Type D WT with droop controller

\section{RESULTS AND DISCUSSION}

A disturbance in the form of a unit step input equal to 0.2 p.u emulating a sudden load increase is applied in the simulation at 10 s as shown in Figure 20 and the frequency of the system at the load end measured for three cases is shown in Figure 21. The wind speed for all the measurements is maintained constant at $10.8 \mathrm{~m} / \mathrm{s}$ [13].

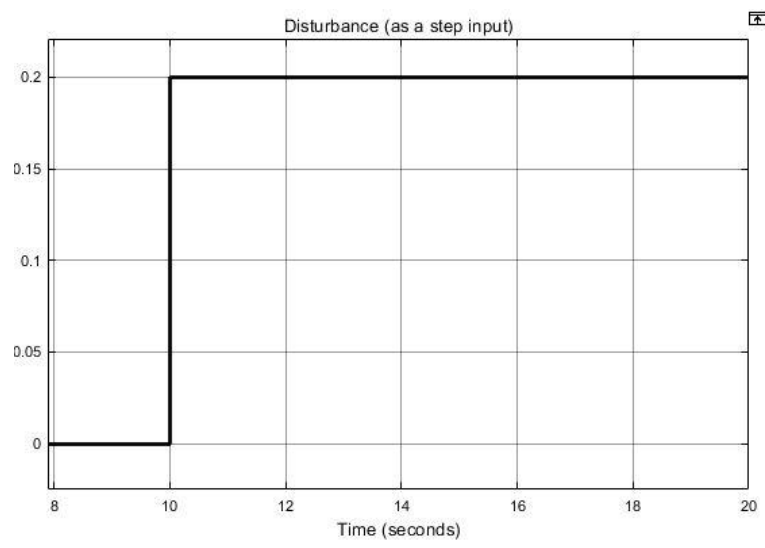

Figure 20. Disturbance of 0.2 p.u at $10 \mathrm{sec}$

For the case of no frequency control contribution from the wind turbine, the frequency drops to $49.83 \mathrm{~Hz}$. In this case the primary frequency control is provided completely by the conventional generator. The frequency oscillates until 20 seconds before stabilizing at $50 \mathrm{~Hz}$.

For the case of inertial controller, the frequency drops to $49.91 \mathrm{~Hz}$ which means that by emulation of inertia from the wind turbine the drop in frequency is less. The oscillations are more in this case as the turbine goes in to recovery mode.

For droop controller, the frequency drop is $49.87 \mathrm{~Hz}$ but, in this case, there is no overshoot in the frequency.

Figure 22 shows the power output of the wind turbine for the case of inertial and droop controller. Before the disturbance the wind turbine is producing a power equal to $0.9 \mathrm{p} . \mathrm{u}$ corresponding to a wind speed of $10.8 \mathrm{~m} / \mathrm{s}$. As soon the disturbance occurs the inertial controller provides a surge in power reaching 1.23 p.u. This surge is provided by using the inherent inertia of the turbine rotors and plays a part in controlling the frequency drop. After the surge, the turbine enters a recovery phase and 
the speed of rotor drops. For droop controller the power surge reaches 1.08 p.u.

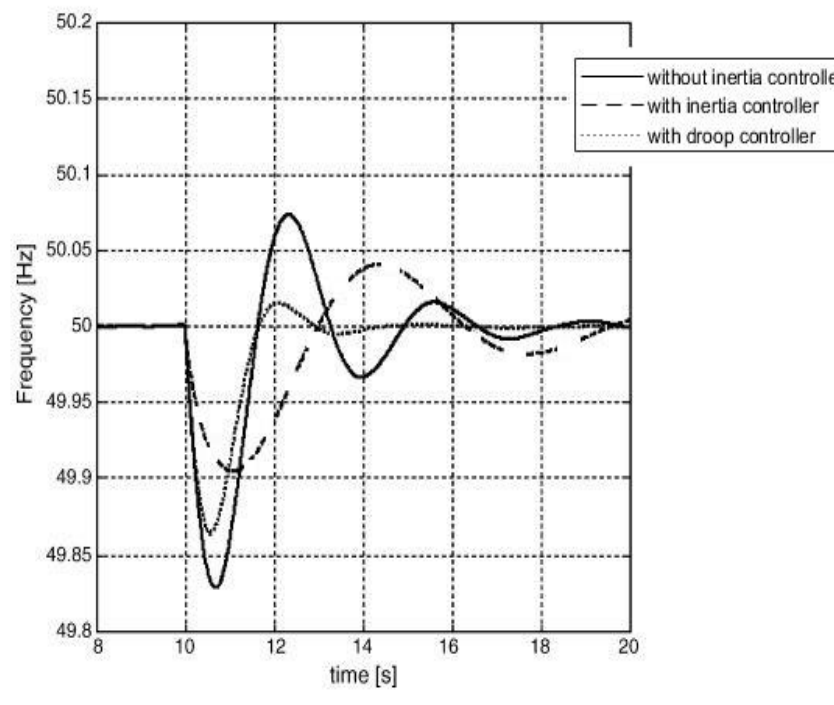

Figure 21. Frequency deviation after disturbance. a) Without inertial controller - solid line b) with inertial controller - dashed line c) with droop controller - dotted line

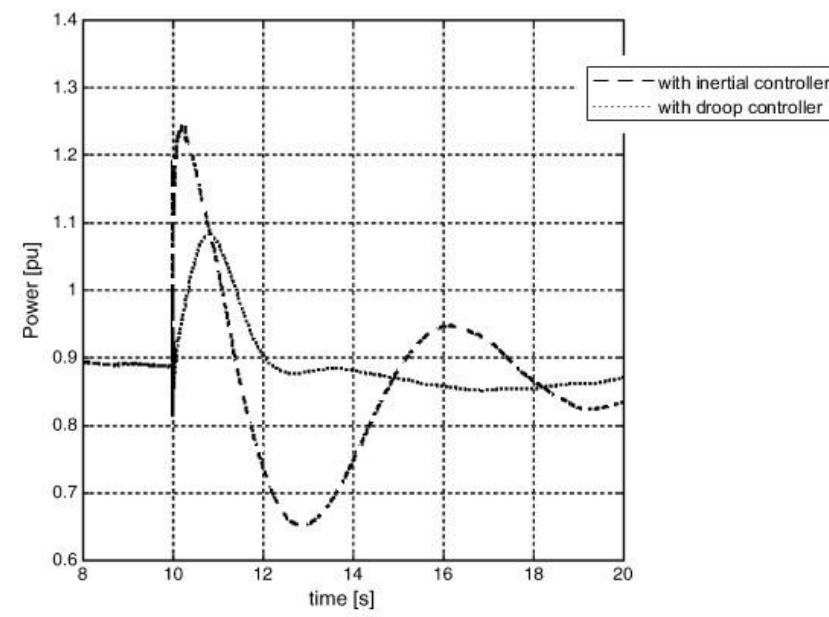

Figure 22. Power output of wind turbine [p.u] for inertia and droop controllers

\section{CONCLUSION}

The use of high percentage of wind power in a microgrid can cause severe frequency stabilization problems. There is therefore a need of inertia emulation from the wind turbines. The inertial controller and a droop controller for providing such frequency control are designed in this paper and the performances of both the controllers are compared. The droop controller tends to have better frequency stabilization performance while the inertial controller has the least amount of frequency dip in the case of a disturbance.
The results show that inertial and the droop controller implemented in this paper, support the dropping frequency which is vital in isolated power systems with high wind power penetration with less spinning reserve. This contribution from the wind turbine not only eases the pressure from the conventional generator but can also lead to reducing reserve generation requirements in the case of a large power system which can be translated to reduction in economic costs.

\section{REFERENCES}

[1] Leung D. and Yang Y., "Wind energy development and its environmental impact: a review," Renewable and Sustainable Energy Reviews, 16(1):1031-1039, (2012).

[2] Yingcheng X. and Nengling T., "Review of contribution to frequency control through variable speed wind turbine," Renewable Energy, 36(6): 1671-1677, (2011).

[3] TransEnergie H. Q., "Technical requirements for the connection of generation facilities to the hydro-quebec transmission system-supplementary requirements for wind generation" (2003).

[4] Holdsworth L., Ekanayake J. B. and Jenkins N., "Power system frequency response from fixed speed and doubly fed induction generator-based wind turbines," Wind Energy: An International Journal for Progress and Applications in Wind Power Conversion Technology, 7(1): 21-35, (2004).

[5] Ramtharan G., Jenkins N. and Ekanayake J., "Frequency support from doubly fed induction generator wind turbines," IET Renewable Power Generation, 1(1): 3-9, (2007).

[6] Akbari M. and Madani S., "Participation of DFIG based wind turbines in improving short term frequency regulation," 18th Iranian Conference on Electrical Engineering, 874-879, (2010).

[7] Marnay C. Spyros C., Chad A.,Reza I.,Geza J., Pio L., Mancarella P. and Appen J.V., "Microgrid evolution roadmap,"2015 International Symposium on Smart Electric Eistribution Systems and Technologies (EDST), 139-144, (2015).

[8] Dreidy M., Mokhlis H. and Mekhilef S., "Inertia response and frequency control techniques for renewable energy sources: A review," Renewable and Sustainable Energy Reviews. 69: 144-155, (2017).

[9] Hansen A. D. and Margaris I.D., "Type IV wind turbine model," DTU Wind Energy, (2014).

[10] Hansen A. D., "Introduction to wind power models for frequency control studies," (2016).

[11] Saadat H., "Power systems analysis". McGraw-Hill, (2002).

[12] Gagnon R. and Brochu J., "Wind Farm-Synchronous Generator and Full Scale Converter (Type 4) Detailed Model," 1997-2009, (2006).

[13] Xie L., Carvalho P., Ferriera L., Liu J., Krogh B., Popli N. and Ilic M.. , "Wind integration in power systems: Operational challenges and possible solutions," Proceedings of the IEEE, 99(1): 214-232, (2010). 